\title{
黑毛和種子牛にみられた軟骨異形成性矮小体躯症の1例
}

\author{
北橋恵実 ${ }^{1)} \quad$ 吉村麻希子 ${ }^{1)} \quad$ 小池正充 $^{1)} \quad$ 高島恵輔 $^{21}$ \\ 菊池元宏 ${ }^{1)}$ 渡辺大作 ${ }^{1)} \quad$ 小山田敏文 ${ }^{1)} \quad$ 大浪洋二 $^{11}$ \\ ${ }^{1)}$ 北里大学獣医学部獣医学科 \\ ${ }^{2)}$ NOSA I盛岡 北岩手家畜診療所
}

\section{Chondrodysplastic dwarfism in a Japanese Black calf}

\author{
E. Kitahashi ${ }^{1)}$, M. Y oshimura ${ }^{2)}$, M. Koike ${ }^{1)}$, K. T akashima ${ }^{1)}$, \\ M. Kikuchi ${ }^{1)}$, D. Watanabe ${ }^{1)}, \mathrm{T}$. Oyamada $^{1)}$ and $\mathrm{Y}$. Oonami ${ }^{11}$ \\ ${ }^{1)}$ School of Veterinary Medicine, Kitasato University \\ ${ }^{2)}$ Kita Iwate Veterinary Clinical Center, Morioka Agricultural Mutual A id A ssociation
}

\begin{abstract}
要 約四肢の著しい短小化口水頭症樣の頭部形状と歩行異常を呈した矮小体躯症の黑毛和種崔牛 を 5 日齢より約 6 ヶ月間飼育し口発育状況を観察するとともに血液生化学検査、内分泌検査および度学 的検査を実施した口 5 日歯時の体重は $25 \mathrm{~kg}$ 体高は50 cm】 体長は5 $2 \mathrm{~cm}$ と著しい低体高であり口X線検 査で長骨骨端板の不明瞭化と溙関節の関節腔の拡大か認められ口CT 検査では大腿骨頭と寛骨臼の離開

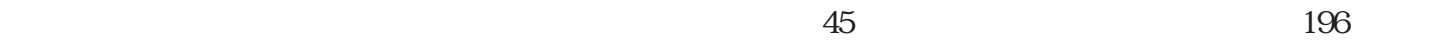
死亡した口本症例では褐毛和種牛の矮小体躯症の原因遺伝子は正常ホモ型であった口内分泌検査では血 漿成長ホルモン濃度の高値、インスリン樣成長因子-1濃度の低値口甲状腺ホルモン ( $\left.T_{3}, T_{4}\right)$ 濃度の 低下がみられたロ病理検査では骨端板の軟骨異形成がみられロ甲状腺ではコロイド濾胞の大小不同と濾 胞上皮のコロイド内への剥離脱落がみられた口症例は軟骨異形成性矮小体躯症と診断したが原因の解 明には至らなかったロ ——ーワード：軟骨異形成口 矮小体躯症』 黑毛和種子牛
\end{abstract}

\begin{abstract}
A female Japanese Black calf presented with dwarfism, extremely small limbs, hydrocephalus-like head, and abnormal gait. It was reared from the age of 5 days to about 6 months to observe its development, and to conduct blood chemistry tests, endocrinological tests, and epidemiological tests. At age 5 days, the calf weighed $25 \mathrm{~kg}$, and had the very small height of $50 \mathrm{~cm}$, and the body length of $52 \mathrm{~cm}$. X-ray examination revealed blurring of long bone epiphyseal growth plates, and enlarged articular cavity of the knee. CT showed separation of the femoral head from the acetabulum. The calf's subsequent development was poor, and it weighed only $45 \mathrm{~kg}$ at age 5 months. A fterwards, it developed astasia, and died at the age of 196 days. The gene that causes dwarfism in Japanese Brown cattle was the homozygous normal genotype in this subject. Endocrinological tests revealed elevated plasma growth hormone, decreased insulinlike growth factor-1, and decreased thyroid hormones ( $T_{3}$ and $\left.T_{4}\right)$. Pathological tests showed chondrodysplasia of the epiphyseal plates. The thyroid showed variability in the size of colloidal
\end{abstract}

Received 10 January 2008/ A ccepted 20 Feburuary 2008

* Correspondence to: M. Kikuchi, School of Veterinary Medicine, Kitasato University, T ow ada, 034-8628, Japan ( ₹ 034-8628 青森県十和田市東23番町35-1 北里大学獣医学部獣医学科)

E-mail : kikuchi@vmas.kitasato-u.ac.jp 
follicles and sloughing off of the follicular epithelium into the colloid. A lthough the animal was diagnosed with chondrodysplastic dwarfism, the cause could not be fully elucidated.

Key Words : chondrodysplasia, dwarfism, Japanese Black calf

Jpn. J. V et. Clinics 31( 1):18-23, 2008

緒 言

牛の矮小体躯症に関しては口 長骨の成長点である骨端 板における軟骨異形成を主病変とする先天性疾患として 多くの報告がある [ 3-5, 9-11, 15, 18, 20] 遺伝に起 因する矮小体躯症は世界中の多くの品種で発生か認めら れ [10]ם 弚の表現型は多樣であるが口 イギリスとオー ストラリアにおけるデキスター種のブルドック子牛は常 染色体劣性または不完全優性の遺伝病として知られてい る $[5,11]$ 日本では口宮崎県と熊本県で褐毛和種にお ける発生がみられ $[9,15] \square$ これらは常染色体劣性遺伝 病であることか確認されており口遺伝子診断が可能となっ ている [21, 22]】しかしい 黑毛和種では発生が報告され ていないので遺伝的背景も不明であるい

一方口 飼料が原因と考えられるものとしてい カナダと アメリカでは妊娠中の母牛にカビの生えたサイレージま たは穀物ワラを給与したことによる発生 $[3,18,19]$ オーストラリアでは干ばつによる重度の栄養不良による 発生 [ 4] と口 母牛の血清マンガン (Mn) 欠乏による 発生 [14] が報告されているまた口 アメリカでは古く からオークの実の摂取による“ acorns calf disease” と しての矮小体躯症が知られており [ 2 ] この他に野生 のルピナス (ハウチハマメ) 搔取による“ crooked calf disease" の発生が報告されている [20]0

本研究では口矮小体躯症の黑毛和種雌牛を 5 日齢から 約 6 ヶ月間飼育して発育状況を観察するとともにロ 本症 の原因究明の一助とするためいくつかの検査を行なつた口

\section{症 例}

症例は黑毛和種雌牛で初診時 ( 5 日齢) の体重は25 $\mathrm{kg} \square$ 体高は50 cm】 体長は52 cm】 斜体長は58 cmで 著し い低体高であった口症例の家系は口 父が気高・田尻系口 母の父が藤良系口祖母の父が田尻系であった口本牛は口 正常分婏で婏出され口在胎期間は284日であつた口また口 母牛に放牧経験はなくロ アカバネワクチンは毎年接種さ れておりロこれまでに先天異常子の出産経歴はなかった口 外観は四肢が著しく短小化し口四肢の各関節が軽度に湾 曲していた口 また口腰部背線は陥没し口体型は図 1-aの ように不均衡であった口歩行は着地時に膝関節部分が固 定されず外側にずれるためロ 後躯全体が着地した方向に 摇れる非常に不安定な歩行を示した口また口頭部は体に

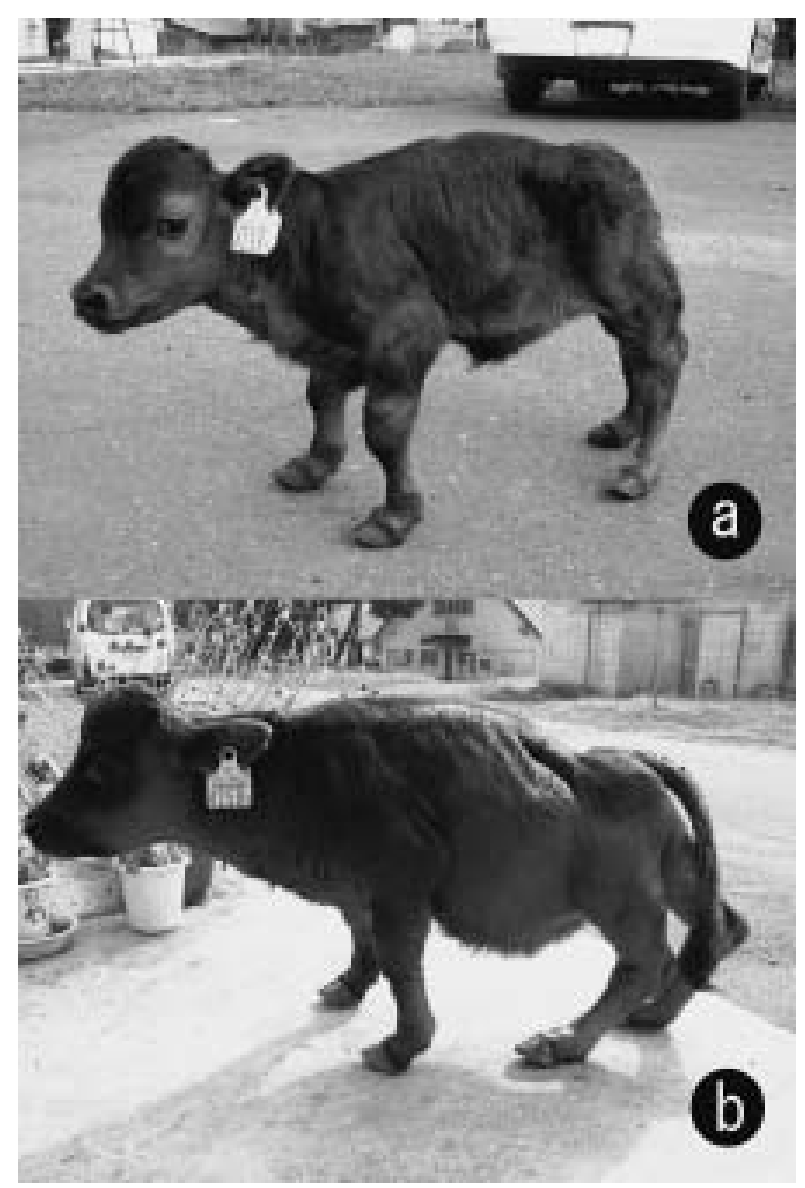

図1，症例の外観

$\mathrm{a}: 5$ 日齢。著しい四肢の短小化と水頭症様の頭部形状 b：58日齢。体重増加に伴う顕著な後肢関節の湾曲、腰 部背線の陥没

比べ大きくロ 額は幅広く～前頭部は突出して水頭症樣の 形状を呈していたロ

飼料給与と発育経過：28日齢までは人工乳口29日齢か らは人工乳と併用してスターター (代用乳) を与えロ 87 日齢に離乳させた口关の後は乾草とスターターを】 174 日齢からは乾草と育成用配合飼料を給与した口 飼育期間 中時折鼓脹症が見られたが体重は 5 日齢から 5 カ月齢 頃までは僅かながら増加を示した口しかしロ 5-45日齢 までの1日増体量 (DG) は0.11 ( kg/日)】46-142日齢ま でのDGは0.16と著しく発育不良であった口体重の増加 に伴い後肢が徐々に体重を支えられなくなり口関節の湾 曲がより顕著になった (図 1 -b) ○关の後次第に歩行困 難になり口 5 ヶ月齢頃からは起立不能になった口 193日 齢に低血糖性ショックを起こして意識混濁となったため口 治療を行なったが低体温口発咳口不整呼吸口肺炎症状 
表1.

\begin{tabular}{lrlr}
\hline \hline $\operatorname{RBC}\left(10^{4} / \mu \mathrm{I}\right)$ & 1061 & $\mathrm{TP}(\mathrm{g} / \mathrm{dl})$ & 5.7 \\
$\mathrm{Ht}(\%)$ & 44.1 & $\mathrm{~A} \mathrm{lb}(\mathrm{g} / \mathrm{dl})$ & 3 \\
$\mathrm{Hb}(\mathrm{g} / \mathrm{dl})$ & 14.1 & $\mathrm{~A} / \mathrm{G}$ & 1.11 \\
$\mathrm{MCV}(\mathrm{fl})$ & 41.6 & $\mathrm{Glu}(\mathrm{mg} / \mathrm{dl})$ & 85 \\
$\mathrm{MCH}(\mathrm{pg})$ & 13.6 & $\mathrm{~T}-\mathrm{cho}(\mathrm{mg} / \mathrm{dl})$ & 59 \\
$\mathrm{MCHC}(\mathrm{g} / \mathrm{dl})$ & 32.7 & $\mathrm{BUN}(\mathrm{mg} / \mathrm{dl})$ & 11 \\
$\mathrm{WBC}\left(10^{2} / \mu \mathrm{I}\right)$ & 87 & $\mathrm{Cre}(\mathrm{mg} / \mathrm{dl})$ & 0.59 \\
$\mathrm{PLT}\left(10^{4} / \mu \mathrm{I}\right)$ & 61.7 & $\mathrm{~T}-\mathrm{Bil}(\mathrm{mg} / \mathrm{dl})$ & 0.52 \\
$\mathrm{Na}(\mathrm{mEq} / \mathrm{l})$ & 146 & $\mathrm{~A} \mathrm{ST}(\mathrm{IU} / \mathrm{l})$ & 41 \\
$\mathrm{~K}(\mathrm{mEq} / \mathrm{l})$ & 5.2 & $\mathrm{GGT}(\mathrm{IU} / \mathrm{l})$ & 70 \\
$\mathrm{Cl}(\mathrm{mEq} / \mathrm{l})$ & 106 & $\mathrm{CPK}(\mathrm{IU} / \mathrm{l})$ & 57 \\
\hline
\end{tabular}

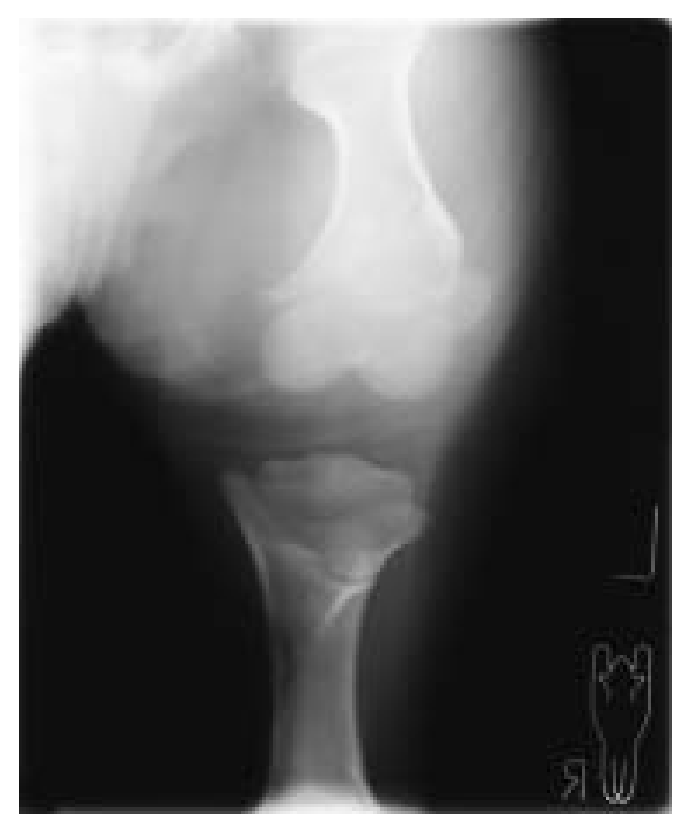

図2。大腿骨と下腿骨のX線所見

長骨骨端板の不明瞭化と膝関節腔の拡大がみられる

\section{を呈しロ 196日齢に死亡した口}

血液検査所見：5日齢時の血液検査では口 特に異常は 認められなかった口（表1)】

画像検査所見：X線検査では口 長骨の骨端板の不明瞭 化と膝関節における関節腔の拡大が観察された (图 2) ロ CT 検査では頭部に異常は認められなかったが口 股関節 の寛骨臼の形成が不十分であった口また口大腿骨頭と寛 骨臼は離開していた (图 3) ロ

遺伝子診断・染色体検査成績 : 褐毛和種牛での軟骨異 形成性矮小体躯症の原因遺伝子 (LIMBIN) は口 正常木 モ型であったロ またロ 末梢血中白血球を用いた染色体検 査を実施したが数的異常や構造異常は認められなかっ たロ

内分泌検査所見 : 血漿中の成長ホルモン (GH) 濃度

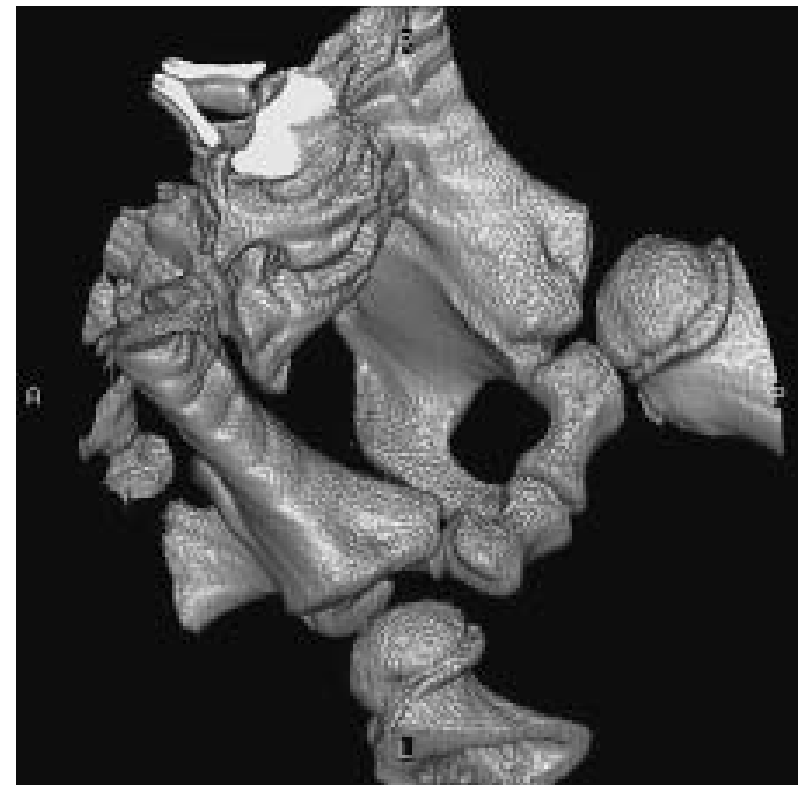

図3。骨盤部CT所見 大腿骨頭と寛骨臼の離開がみられる

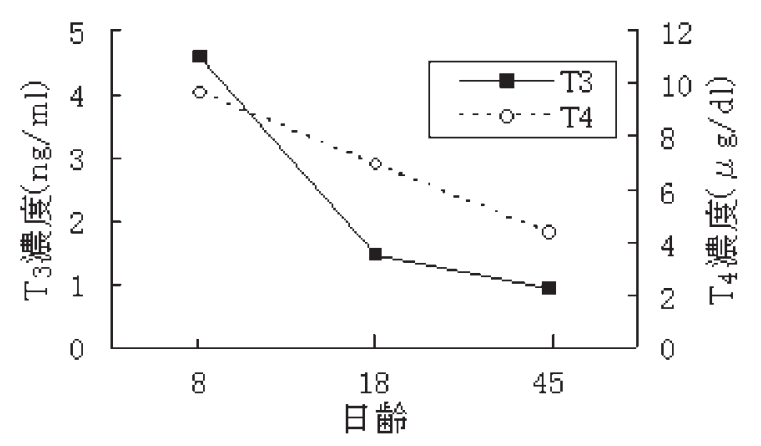

図4，甲状腺ホルモン $\left(T_{3}, T_{4}\right)$ の推移

は口 6 日齢ロ 49日齢のいずれにおいても10.5 17.6 ng / ml の高值を示した口一方口血墏中インスリン樣成長因子1 (IGF-1) 濃度は口 6 日齢では90 ng/mla 49日齢で は $30 \mathrm{ng} / \mathrm{ml}$ と著しい低值を示した口甲状腺ホルモン (トリヨードサイロニン； $\mathrm{T}_{3}$ ロ サイロキシン； $\mathrm{T}_{4}$ ) 濃 度は口 6日齢では正常值であったが 18日齢ロ45日齢で は徐々に低下した (図4)、

病理所見 : 本症例における特徵的な組織学的病変は口 骨と甲状腺に観察された口長骨の骨組織は口 軟骨柱状構 造の形成が不十分で軟骨柱が短縮し口柱状に配列せずロ 軟骨細胞の数は減少していた口（図５）ままた口骨端軟骨 に連続する骨髄腔の骨梁は乏しかったロ 同樣の所見が関 節軟骨口椎骨などで観察された口甲状腺では口 濾胞の大 小不同がみられ、小型の濾胞が多く存在していた口また口 濾胞内のコロイドの染色性は不均一であった口甲状腺全 域で濾胞上皮がコロイド内に录離脱落しロ核濃縮と細胞 質内に好酸性顆粒が認められ変性的であった (図6)】 


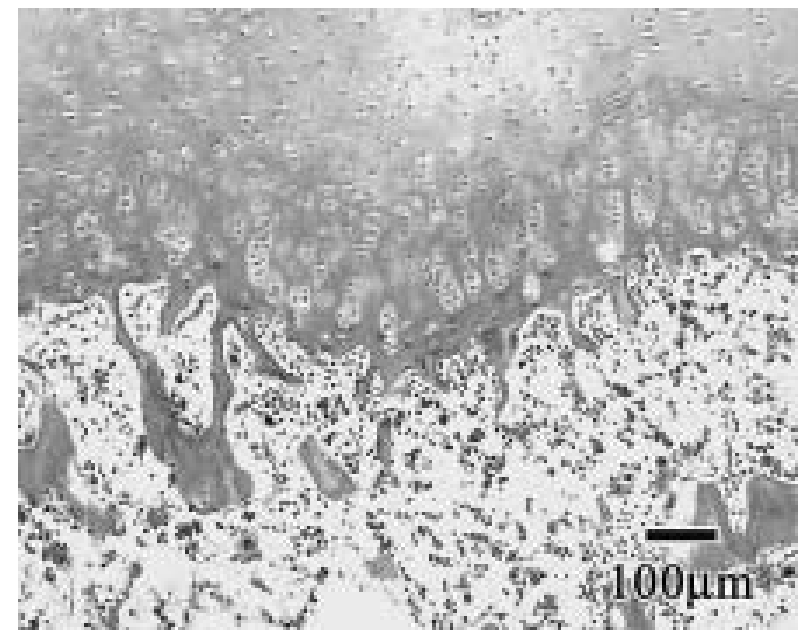

図5，大腿骨近位骨端軟骨 (HE染色) 骨端軟骨における軟骨内骨化の消失が見られる

疫学的調査 : 症例の生産農場では症例以外に 4 頭の子 牛が同年に出生しており口症例を除けば矮小体躯症の発 生は認められていない口給与飼料としてい自家乾草口牧 草ラップサイレージおよび配合飼料が与えられていたが 特に例年と変わったところはなかった口なお口 飼料の力 ビ発生の有無については確認できなかったロ またロ人工 授精された種雄牛の精液は周辺の農場でも多くの牛に授 精されていたが矮小体躯症発生の報告はなかった口

\section{考 察}

牛の矮小体躯症の原因として遺伝が知られているため [ 5, 9, 11, 15] 褐毛和種の軟骨異形成矮小体躯症の原 因遺伝子 [21, 22] について症例の保因を検査したが正 常ホモであった口症例の父牛は多くの繁殖牛に授精され ているにも関わらず口症例以外に発生例の報告がみられ ないことから遺伝病の可能性は少ないと考えられた口野 生のルピナスによる“ crooked calf disease”では口関 節の屈曲口 斜頸口 脊柱彎曲および口蓋裂がみられる [20] がロ 今回の症例ではみられなかった口 またロ カビ の生えたサイレージや穀物ワラの給与による発生 [ 3, 18, 19] も報告されているが口本症例については飼料が 残されておらず口 乥の関与を明らかに出来なかったが口 母牛に同樣の飼料を給与されたと思われる他の子牛に発 生は認められなかった口 また口聞き取り調査から栄養不 足の関与も特に考えられずロ 原因を特定することはでき なかったロ

症例は軟骨異形成による四肢の短小化と四肢の外反口 歩行異常およびドーム状の頭蓋を特徵としていたロ 正常 な骨成長は口 栄養因子、 GH口 甲状腺ホルモンロ 性ステ ロイドなどのホルモンにより制御されている [16]ם こ

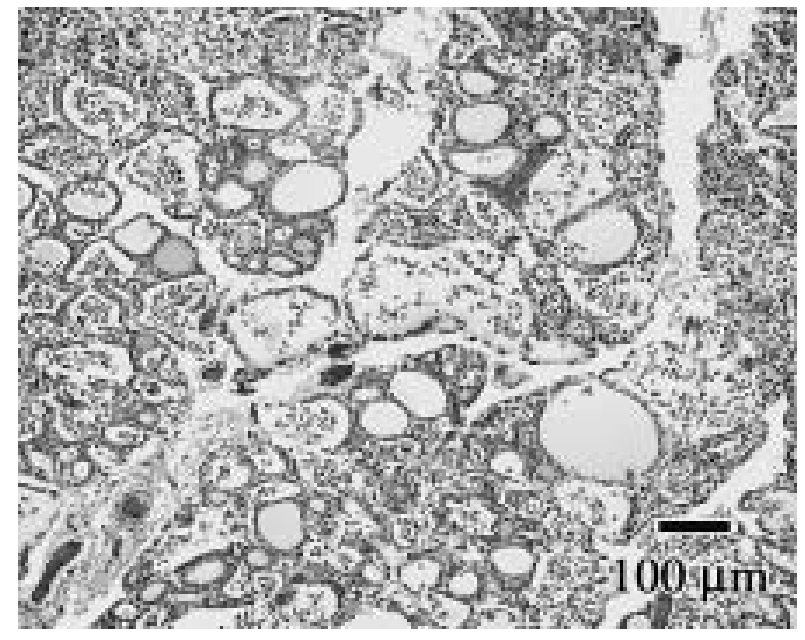

図6。甲状腺 (HE染色)

甲状腺濾胞上皮の大小不同、上皮細胞の剥離が見られる

のうちGHは脳下垂体前葉から分泌され口骨の胚芽細胞 層の未分化軟骨細胞の分裂を刺激すると同時に肝臓での IGF-1 産生を刺激し口産生されたIGF-1 はGH刺激を受 けた骨の増殖細胞層の細胞増殖を促進するロこのように GH とIGF-1が作用して長軸方向への骨成長に関与する [17]ם症例では血漿GH濃度の高值にも関わらずロ 血漿 IGF-1 濃度の著明な低值がみられた口牛において血漿 IGF-1 濃度は口 代謝エネルギ一量口粗蛋白質量などの栄 養撖取量の影響を受け口低栄養状態では高栄養状態より も低値となることが知られている [ 7]ם今回ロ ホルモ ン測定と同時に行った血液検査では口 栄養摂取マーカー となる血液成分も正常範囲にあった口このことからロ低 栄養状態による血漿IGF-1濃度の低下ではないと考えら れたロ

血漿GH濃度の高値とIGF-1 濃度の低值を示すものと してロヒトではGH受容体の遺伝的異常によるLaron型 小人症が報告されている [12]ם Laron型小人症は口低 身長口発育遅延口肥満口先端矮小症口前頭部突出などを 特徵とし口 外因性GHに無反応であるとされている [ 1， 12] 本症例はホルモン動態ではヒトのLaron型小人症 に類似していたがロ 外因性GHに対する反応性はみてい ないためロ 血漿IGF-1 濃度の著しい低值が肝藏のGH受 容体の異常あるいはIGF-1の生成異常に由来するかは明 らかに出来なかった口

症例の甲状腺では口 小型の濾胞が多く存在しロ 濾胞の 大小不同 濾胞上皮の变性がみられた口正常な牛の甲状 腺は胎齢 2 ～ 3 カ月で小胞とコロイドが認められるが 先天性の形態異常としては無形成や低形成が報告されて いる [6，8]口 また口胎生期の甲状腺ホルモンは口 体の 脂質代謝や血中のコレステロール代謝 器官の分化に影 
響するロ そ次乏は生後の骨格発達の異常や中枢神経の 発達異常を生じロこれにより起こる疾患をヒトではクレ チン病 (先天性甲状腺機能低下症) といい口甲状腺ホル モン (サイロキシン； T ${ }_{4}$ ) の欠乏により軟骨内骨化が 障害され口骨伸長や仮骨中心の発現が遅れる [13]ם 症 例は口甲状腺ホルモン測定結果から 6 日齢では $T_{3} \square T_{4}$ ともに正常範囲内でありロ クレチン樣の疾病ではないと 考えられたロ

内分泌学的検查および病理組織学的検査成績から口本 症の主病変である四肢長骨の短小化は口長軸方向への成 長点である骨端板の軟骨形成不全に基づく軟骨内骨化の 異常によるもので 長骨が太くなった原因としては長骨 の短小化に対して軟骨の付加成長である膜内骨化が正常 に行なわれていたためと考えられたロ またロ 歩行異常は 膝関節部 (大腿骨遠位端口下腿骨近位端) の骨端部变形 による関節結合の不整のためと考えられたロ

今回の症例は軟骨異形成性矮小体躯症と診断したが 原因の解明には至らなかった口 今後症例を集めて兴の病 態と原因を探求したい口

稿を終えるにあたり口軟骨異形成症の遺伝子診断を行 なっていただいた岡山大学大学院自然科学研究科 国枝 哲夫教授に感謝するロ

\section{引用文献}

1. A mselem S, Duquesnoy P, Attree O, Novelli G, Bousnina S, Postel-V inay MC, Goossens M (1989) Laron dwarfism and mutations of the growth hormone-receptor gene. N Engl J Med, 321 : 989 995

2. Barry MR, Murphy W JB (1964) A corn calves in the A lbury district of New South Wales. A ust Vet J, $40: 195-198$

3. Cebra KC, Cebra LM, Ikeda OB (1999) Congenital joint laxity and disproportionate dwarfism in a herd of beef cattle. J A m Vet Med A ssoc, 215 : 519-521

4. Court BH (1994) Congenital joint laxity and $\mathrm{dw}$ arfism in calves. A ust V et J, 71:58

5. Crew FAE (1923) The significance of an achondroplasia-like condition met $w$ ith in cattle. Proc Royal Soc Biol, 95 : 228255

6. 江口保暢, 橋本善之 (1959) 牛胎子甲状腺の組織学 的所見. 日畜会報, $30: 103-108$

7. Elsasser HT, Rumsei ST, Hammond CA (1989)
Influence of diet on basal and growth hormonestimulated plasma concentrations of IGF-1 in beef cattle. J A nim Sci, 67 : 128-141

8. Ferguson DC (1994) 甲状腺疾患 (宮沢恵子訳). 獣医臨床シリーズ1996年版, $24: 31-38$, 学空社, 東京

9. 浜名克己, 下別府 功 (1983) 牛の先天異常 : 1972 1981年に宮崎県において観察された482例．家畜繁 殖誌, $29: 1820$

10. Hamori D (1983) Constitutional disorders and hereditary diseases in domestic animals. 341-346, Elsevier Scientific Publishing Company, New Y ork

11. Harper P, Latter MR, Nicolas FW, Cook RW, Gill PA ( 1998) Chondrody splasia in A ustralian Dexter cattle. A ust V et J, 76 : 199-202

12. Laron Z, Pertzelan A, Karp M, Kow adlo-Silbergeld A, Daughaday WH (1971) Administration of growth hormone to patients with familial $d w$ arfism with high plasma immunoreactive growth hormone : measurement of sulfation factor, metabolic and linear growth responses. J Clin Endocrinol Metab, 33 : 332-342

13. McDonald LE (1980) Veterinary Endocrinology and Reproduction. 3 rd ed., 148-207, Lea\&Febiger, Philadelphia

14. McLaren PJ, Cave JG, Parker EM, Slocombe RF (2007) Chondrodysplastic calves in Northeast V ictoria. Vet Pathol, $44:$ 342-354

15. 森友靖生, 石橋武彦, 芦沢広三, 芝田 猛 (1989) 褐毛和種の子牛に見られた軟骨異形成性矮小体躯症. 日獣会誌, 42: 173-177

16. Nilsson A, Ohlsson C, Isaksson OG, Lindahl A, Isgaard J (1994) Hormonal regulation of longitudinal bone growth. Eur J Clin Nutr, $48: 150-158$

17. Ohlsson C, Nilsson A, Isaksson O, Lindahl A, (1992) Growth hormone induces multiplication of the slowly cycling germinal cells of the rat tibial growth plate. Proc Natl A cad Sci USA, 89 : 98269830

18. Ribble CS, Janzen ED, Doige CE (1993) Congenital spinal stenosis and dam mortality associated with feeding moldy cereal straw. Can Vet J, 34: 221225

19. Ribble CS, Janzen ED, Proulx JD ( 1989) Congenital 
joint laxity and dwarfism : A feed associated congenital anomaly of beef calves in Canada.Can Vet J, $30: 331-338$

20. Shupe L, James LF, Binns W (1967). Observations on crooked calf disease. J A m V et Med A ssoc, $151: 191-197$

21. T akeda H, T akami M, Oguni T, T suji T, Y oneda $K$, Sato $H$, Ihara $N$, Itoh $T$, Kata SR, Mishina $Y$, Womack JE, Moritomo Y, Sugimoto Y (2002) Positional cloning of the gene LIMBIN responsible for bovine chondrodysplastic dwarfism. Proc Natl A cad Sci USA, 99 : 10549-10554

22. Yoneda K, Moritomo $\mathrm{Y}, \mathrm{T}$ akami M, Hirata S, Kikukawa Y, Kunieda T (1999) Localization of a locus responsible for the bovine chondrody splastic dwarfism (bcd) on Chromosome 6. Mamm Genome, 10 : 597-600 